\title{
FUNCTION OF THE ELECTRICAL SUPPLY ENGINEER IN WARTIME
}

TN the War of 1914-18 the supply engineer put to 1 the service of the State his lnowledge of the habits and business of those who lived and worked within his area of supply, not only as an individual but also backed by all the resources of his undertaking. Faced to-day with a similar crisis, Mr. J. W. Beauchamp, of the Central Electricity Board, recalls in an article published in Electrical Industries of November, what the supply engineer did during 1914-18. His main object was to assist the Ministry of Munitions and the Coal Control by pooling stoclis, giving holp in repairing damage or speeding up power supplies and dealing with the moro difficult problem at that time of rotaining skilled staff. All these were the subject of collectivo action.

The work was done with few formal meetings, but a large amount of personal effort and attention was given on the part of the staff. To-day the maintenance of supply and safety of the staff offers $a$ much greater preoccupation. There is little time for discussion or inclination to go far from one's base, but the industry possesses a central dovelopment organization uniting all together, and ablo to pool ideas and unify action. The Commissioners and the Central Board in their respectivo spheres have formed a bond between the undertakings, and the Ministry of Supply itself includes the first chairman of the Central Electricity Board, a man whose work has left a great mark on tho electrical industry of Great Britain.

Although reticence has become a virtue, few can fail to realize the great difference now governing the supply of lighting material and thoso which had to bo mot and remedied in the early years of the last war. Great factories created solely for defence can be supplemented by many but little smaller, which can be quickly turned from their peace-time activity to the production of the commodities required to keep a fighting force in action and make up its wastago.
Much of the remarkable improvisation of 1914-18 can be avoided, but if and when it becomes desirable to onlist still more and perhaps smaller industrialists, it should bo easy for authority again to utilizo the local knowledgo of the supply engineors and their staffs. In most cases they have the entréo to works of every kind in their areas and tho confidence of the owners, and can often without delay suggest sources of supply and existing plant and labour easy to adapt to the mass production of simple items or components for uso by moro specialized manufacturers. The parcelling out of such work is not without benefit as it stimulates local interest, holds together business valuable in peace-time, reduces dislocation of local labour and trado, bringing with it opportunities of training unskilled persons, and as has often happened in the past, introduces into local works methods of production and degrees of accuracy which provo of valuo when normal labour is resumed.

In 1914 we had no experience of a contest between highly mechanized States. A thousand devices of attack and defence had been as yet unborn. Abovo all, there is the air menace which makes frontiers a plane rather than a line. In the electrical industry, the interval covers many changes, notably great collective control, administration by the Commissioners, operation by the Board, development and research by associations, and a closo co-operation amongst those who produce and instal electrical appliances.

The outlook of the public towards electricity is now quite different. 'To-day all branches of the industry in combination provide the greatest public utility in the modern State, and the one in which the operators and their staffs have the most direct and frequent contact with the millions who use electricity for personal service or as a component in their trade or industry.

\section{TRIBAL ORIGINS AND CULTURE AMONG THE FOX INDIANS}

\begin{abstract}
A $N$ ethnographical account of the Fox Indians has recently been issued by the Smithsonian Institution. It has been edited by Margaret Welploy Fisher, and is based upon material which has an exceptional claim to authority. 'The author, William Jones, was born on the Sauk and Fox Reservation in Oklahoma in 1871. His mother was English, but his father was the son of a white man and an Indian mother. Up to tho age of nine years, Jones was reared by his Indian grandmother, living the life of an Indian boy. On her death and after a period as a cowboy, he entered the Hampton Institute, passed to Andover and Harvard, taking the degree of M.A. at the latter in 1900 and Ph.D. in 1904. His intention

* Ethnography of the Fox Indians. By William Jones, edited by Yrargarct Welpley Fisher, (Bureau of American Ethnology, Bull. 125.) Pp. iv + 156. (Washington, D.C.: Smithsonian Institution, 1939.)
\end{abstract}

had been to study medicine; but under the influence of the late Prof. Putnam he turned to anthropology, spending his vacations in field work among Algonquian tribes and making a comparative study of Algonquian religions. This field, however, afforded little hope of a career in research; and in 1906 the Field Museum offered him the choice of three expeditions, of which he elected for an expedition to the Philippine Islands. In the spring of 1909 he was murdered by the Ilongots.

Before his departure for the Philippines, Jones had already published some of the material he had collected in the field, while other studies were issued posthumously. 'The greater part of his papers, howover, and that containing what now appears to have been the more valuable results of his inquiries, was missing. Its whereabouts was unknown until, on the 
death of his father a few years ago, it was disclosed by the family lawyer, who forwarded the papers to the Smithsonian Institution, that the father of William Jones had kept the existence of these papers a secret, as he had felt that much of the information divulged to his son had been due to his omn friend. ship with the Foxes and, therefore, had been unwilling that it should bo published during his lifetime.

A sealed packet said to have contained an account of "ancient mysteries" nevor previously revealed to a white man, to which reference is made in "William Jones" by Henry Rideout, has not yot been identified with certainty, although its existence has been confirmed by inquiry. Certain passages in the present account are indicated tentatively as possibly embodying this material.

i he Fox Indians aro of particular interest as culturally intermediate between the tribes of the castern woodlands and thoso of tho Great Plains. Their languago is the most archaic of the Algonquian tongues; and with tho Mexican Kickapoo, their kindred, they rank among the most conservative of all Indians. Hence until a fow years ago, they woro regarded as representing in their culture an archaic Fox pattern, and considered types of the "Central Algonquian". Examination of their history has wealened this view and indicates that there is no means of knowing how far it represents the truth. Acculturation has been carried to such lengths that it would be remarkable if many specifically Fox traits remained.

I nowledge of Fox history begins in 1640, when the Huron map was drawn up for the Jesuits. They hand then been driven westward by hostile tribes, with whom they continued in conflict until the arrival of French traders in 1665. From that time onward, the French waged a war of extermination against the Foxes, whose country on the Fox.
Wisconsin waterway was a preferred route to the Mississippi and a strategic point for trade. Failuro to secure their adhesion to a French schemo of pacification of Indian tribes with Detroit as the concentration point embittered a struggle which culminated in the virtual extinction of the Foxes in $172 \mathrm{~s}$, when they were intercepted while trying to escape into Iroquois country. After a conflict lasting twenty-three days, only somo fifty or sixty got away alive, or as it iras expressed afterwards by a member of the tribe, in speaking of the wars with the French, "once there were only 3 lodges of the Fox Indians left".

However, in the winter following the massacre, the membership of the Fox tribe had risen again to 250 . This and previous regenerations of the tribe had been effected in two ways. Prisoners wero captured in war for the purpose of adoption into the tribe-the Pawnees, in particular, had been tho victims of such attacks; and through the good offices of western allied tribes, Foxes who wero held prisoners by hostile tribes wore released and allowed to roturn to augment the tribo. Theso two elements, though politically all members of the Fox tribe, culturally had wide and various roots.

In the numerous vicissitudes and migrations of the tribe, in which they suffered soverely from cholora and smallpox, settloments wero formed in Kansas, Iowa and Oklahoma. The records show a close and prolonged association with the Sauk, and the incorporation of elements from Potawatomi and Winne. bago. A tribo thus many times depleted and restocked, although strongly resistant to white culture, is scarcoly likely to have escaped the cultural influenco of the many and intimate relations with other tribes. Hence at the time information was collected by William .Jones, any assumption of tho archaic and original pattern of Fox culture had becomo hazardous.

\section{GRASSLAND AND FORAGE CROPS IN THE UNITED STATES}

\begin{abstract}
INIOIRAIION with regard to forage crops, range I management and the botanical aspects of soil conservation in tho United States is either not availablo in published form or is scattered among a large number of reports. The Imperial Bureau of Pastures and Forage Crops at Aberystwyth has accordingly prepared a bulletin, compiled by R. O. Whyte, entitled "Research on Grassland, Forage Crops and the Conservation of Vegetation in the United States of America" (Herbage Publication Series, Bulletin 26. 5s.).

The bulletin deals first with the work of the Division of Forage Crops and Diseases, each of the five crop groups being studied from the point of view of culture and production, breeding and improvement, and diseases. An important recent dovelopment has been the organization of the U.S. Regional Research Laboratory, State College, Pennsylvania, which should become one of the leading world centres for the study of problems connected with humid temperate pastures. The range investigations of the Forest Service are then described. These aro intended
\end{abstract}

to supply basic information for the intelligent utilization of the land, the field work being organized into six regional forests and range oxperiment stations, covering the western United States. The research of tho Soil Conservation Service deals with many aspects other than the use of grassland and forage crops as a protective cover for soil, and some account is given of the terms of reference of the eight branches of the Division of Research in the S.C.S., information not already published in Bullotin 25 being included.

Brief reference is made to the studies in progress under the auspices of the U.S. Golf Association, and details given of the ecological research at the Carnegie Institution of Washington regarding factor and function in adaptation, climax, succession and conservation.

The remainder of the bulletin contains relevant extracts from the most recent annual reports from practically all the agricultural experiment stations in the United States. 